\title{
Women Empowerment Through Digital Technology
}

\author{
Kapisha Rajput \\ DOI: 10.29322/IJSRP.11.11.2021.p11958 \\ http://dx.doi.org/10.29322/IJSRP.11.11.2021.p11958
}

\begin{abstract}
Information technology has made the world much smaller, faster and easier for people to access it through internet. Internet has revolutionised the way of business through networking, digital marketing and online selling. Moreover, pandemic has proven the importance of digital technology. India, being a developing country is ensuring inclusive and equitable quality education for both girls and boys. As per United Nation's Sustainable Development Goals, Goal 5.b is "There should be enhanced use of information and communication technology, to promote the empowerment of women". In that case, IT, medical and education sector have not remained the only sectors providing equal opportunities in technology to both men and women. In recent years, women entrepreneurs are using technology to step into new sectors with ease and having wider range of customers. Web based businesses / E-commerce has given enormous opportunities to the business sector by giving $24 / 7 / 365$ business connectivity. The involvement of women in various entrepreneurial activities helped them to overcome discrimination, achieve full equality, well being and participation in decisions that impact the quality of their lives and the future of their communities. Web based business helps the women entrepreneur to generate new ideas and work from home for worldwide customers, thus fulfilling their basic needs and raising their self esteem. Digital technology has enabled the usage of low amount of initial investment, good profit ratio, easy payment process, a good reach to gain potential customers, getting the customer feedback through networking and enabling them to work while fulfilling their household responsibilities at the same time, are few things which make entrepreneurship more attractive and much easy for women entrepreneurs.
\end{abstract}

Index Terms- Women empowerment, digital technology, employment, e-commerce

\section{INTRODUCTION}

A s we are moving toward 2030 with a greater agenda of Sustainable Development Goals formulated by United Nations, digitalisation has provided many opportunities for women entrepreneurs. Facilities given to employees because of digitalisation helps in reducing the gap of gender inequality as it encourage women to take up jobs while fulfilling the responsibilities at home. This is a major contribution towards Goal 5 of Sustainable Development Goals. Many established organisations of the country have their online portals for business whereas many new budding businesses are setting up their exclusively online businesses for its relatively less capital intensive nature. This also encourages women to start up their own businesses. E-commerce is defined as the process of buying, selling, transferring or ex-changing products, services or information via computer networks, including the Internet [Turban et al., 2008]. Hunt (2007:1) provided a complete definition of ecommerce: "e-commerce is the use of electronic communications and digital information processing technology in business transactions to create, transform, and re-define relationships for value creation between or among organizations, and between organizations and individuals." Babita [2014] identified that ecommerce as a marketing process or technique that used by business organization, industries and corporation for business through the internet system. In a developing country like India, involvement of women in economic activities is limited by a lack of access to essential resources like education, capital and training etc. In such limited conditions, E-commerce can be an effective platform for starting their own businesses, thus contributing to their family income. It is less costly and a wide range of customers can be tapped around the globe.

This paper attempts to examine the different ways in which digital technology has supported women employment and the problems faced by women entrepreneurs in E-Commerce sector.

\section{BENEFITS OF Digitalisation IN WOMEN EMPOWERMENT}

Global Platform: Technology has provided a global stage for women entrepreneurs in e-commerce sector, bypassing some of the traditional culture of mobility. At the ease of their home, among their family members, fulfilling their daily responsibilities towards their families, women are coming up with much more support from their family and society to acquire and interact with customers at global stage. Women engaging in e-commerce activities at local stage have brought the local market in limelight, creating awareness and educating people.

Safe Environment to Work: Virtual or remote working seems to be a common practice because of Pandemic. Digital Technology has brought a safe environment to work for female employees by giving them the flexibility of workplace. More and more women are willing to start working looking at the work from home facility provided by most of the companies. It gives the power to bridge the equality gap supporting gender equality, when more females are stepping out for work and using technology to do it at the ease of their safe and adaptable home environment.

Work-Life Balance: A statement by CEO of the IBM clearly shows the relation between Work Life Balance and gender diversity. He states, "Workplaces that support gender diversity also tend to have more flexible work-life balance and family leave policies, things that both sexes value and that increase women's ability to participate equally in the workforce." - Eric Berridge, CEO of Bluewolf, an IBM Company.

Digital technology helps in work life balance of female employees providing inclusive career environment for them. Employees are avoiding work related travels and are organising 
virtual meetings. It also encourages gender diversity at the workplace.

Collaborate with Local Partners: Digital technology has provided an enormous support to local small and medium scale industries. Educated women being tech savvy are helping local artisans to showcase their products and promoting Indian Handicraft and handloom industry. There is an upsurge of job opportunities for women in India through digital technology.

\section{Challenges Faced By WOMEN IN E-COMMERCE SECTOR}

Women entrepreneurs face peculiar challenges in an attempt to achieve success (Hatcher et.al., 2007) and women in less developed countries face much more obstacles to formal economic participation than those in developed countries (Allen et al; 2008). Women face unique hurdles in starting and growing their firms such as lack of skill or training, limited access to capital or credit, lack of savings and social networks, and limited choice of industry (Akanji, 2006; Ibru, 2009; Lakwo, 2007; Martin, 1999; Ojo, 2009).

Women need to be Educated and Tech Savvy: According to the World Bank data, in 2020, the rural Indian population constitutes $65.05 \%$ of the overall population. The total female population in India is 662.90 million. The percentage of Female population is 48.04 percent as compared to 51.96 percent of male population. As per 2011 census, $41.25 \%$ of women are illiterates and lack basic educational requirement. Lack of education for women, naturally engages them in very low wage occupations where there is basic need for money. The remaining bulk of rural women spend longer hours in household chores, in farms or agriculture allied activities including cattle rearing, agricultural labor , dairying, poultry farming etc. Income generation and fulfilling their basic needs deprive them of education.

Social obstacles in Women Empowerment: Domestic violence and other crimes committed against women are still a major issue in a developing country like India with major chunk of its population being rural. Rural population discriminates women on caste as well as on social standing. Patriarchal system in rural India is also one of the obstacles in empowering women through technology. All these social obstacles lead to poor access to women education, healthcare and financial stability which is a challenge for Women empowerment.

Initial Capital: Women empowerment through entrepreneurship is not possible if there is unavailability of initial capital. Digitalisation and E-commerce provides an opportunity for women to start their business with little capital with available resources. Market has seen an upsurge in the start ups with new social media providing perfect platforms for showcasing work of talented women at home and earning from it at the same time.

\section{CONCLUSION}

Ensuring that all women are able to use technology for employment and keep adapting to ever changing technology is critical, if the promise of not leaving anyone behind as per Sustainable development Goals has to be implemented. There are many associations made and policies framed by various state governments to encourage women to gain maximum through their participation. SEWA (Self Employed Women's Association) in Gujarat, Gyandoot in Madhya pradesh, M.S. Swaminathan research project in Pondicherry, Smile (Savitri Marketing Institution for Ladies Empowerment) in Pune, Datamation Foundation, Delhi and Aamagaon Soochna Kendra (My village's information centre) in Orissa are few of initiatives taken by respective governments to maximise the use of ICT, Information and communication technology by Women participation. Ecommerce has provided a significant growth for women entrepreneurs. It provided them with necessary financial freedom with sense of responsibility in building up career and at home also. E-commerce helps the women to tap the global market with limited initial investment. It also provides them with the required social status with financial freedom. The only need of the hour is to create awareness among women about e-commerce and fulfilling their basic requirement of training to use these social media platforms for businesses.

\section{REFERENCES}

[1] Anu Madgavkar, James Manyika, Mekala Krishnan, Kweilin Ellingrud, Lareina Yee, Jonathan Woetzel, Michael Chui, Vivian Hunt, and Sruti Balakrishnan (2019) The future of women at work: Transitions in the age of automation, McKinsey Global Institute analysis

[2] Christiane Krieger-Boden and Alina Sorgner, (2018),Labor market opportunities for women in the digital age, published in Global Solutions Paper

[3] Lechman, Ewa, Paradowski, Piotr, (2021), Digital technologies and women's empowerment, published by Taylor and Francis

[4] Mohd, Ishaq Bhat (2019), Women Empowerment and Technology: An Overview, In book: Ethics and Society (pp.44-54, Publisher: The Bhopal School of Social Science

[5] Mehnaz Akhter , (2017), Empowering Women through E-commerceConduit for Women Entrepreneurs in Bangladesh IOSR Journal of Business and Management (IOSR-JBM)

[6] https://www.mckinsey.com/featured-insights/gender-equality/the-future-ofwomen-at-work-transitions-in-the-age-of-automation

[7] www.bsr.org

[8] https://www.g20-insights.org/policy_briefs/empowering-women-digitalage/

[9] https://library.oapen.org/handle/20.500.12657/49781

[10] https://www.researchgate.net/publication/331982270_Women_Empowerme nt_and_Technology_An_Overview

[11] https://statisticstimes.com/demographics/country/india-sex-ratio.php

[12] https://www.iosrjournals.org/iosr-jhss/papers/Conf.17036/Volume3/12.\%2037-39.pdf

[13] https://financialservicesblog.accenture.com/empower-women-in-theworkplace-with-digital

[14] https://www.ibm.com/employment/inclusion/downloads/empowering_wom en_in_tech_ibm_case_study.pdf

\section{AUTHORS}

First Author - Kapisha Rajput 